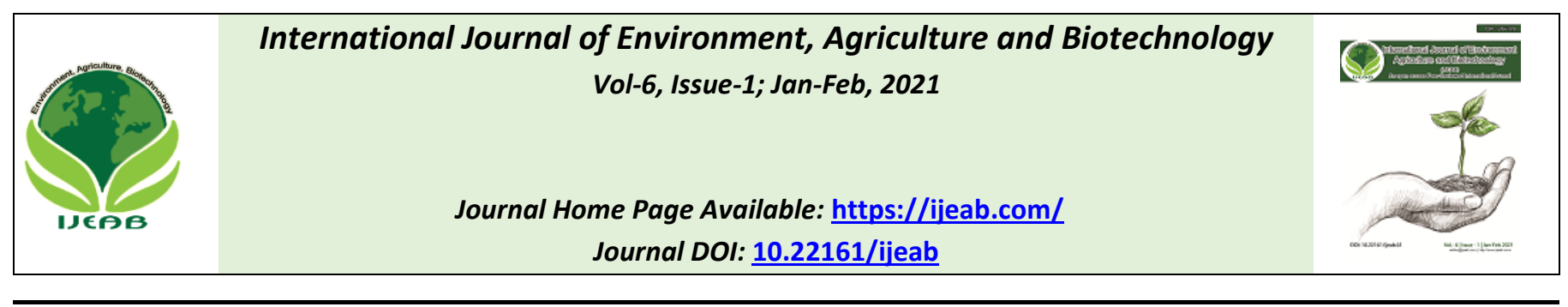

\title{
Utilization of Mesquite Pods for Feeding Kids Grazing the Natural Ranges of Halaib Region
}

\author{
Hassanein S. Badawy ${ }^{1}$, Ahmed H. Mohamed², Mohamed. A. El Shesheny ${ }^{2}$, Moustafa M.A. \\ Ghandour $^{1 *}$
}

${ }^{1}$ Department of Animal and Poultry Nutrition, Desert Research Center, Cairo, Egypt.

${ }^{2}$ Department of Plant Ecology and Rangeland Management, Desert Research Center, Cairo, Egypt.

*Corresponding Author

Received: 06 Nov 2020; Received in revised form: 09 Jan 2021; Accepted: 21 Jan 2021; Available online: 31 Jan 2021

C2021 The Author(s). Published by Infogain Publication. This is an open access article under the CC BY license

(https://creativecommons.org/licenses/by/4.0/).

\begin{abstract}
This study was amid to investigate animal response to replacement $15 \%$ of concentrate feed mixture (CFM) with ground mesquite pods without and with 4\% Polyethylene glycol (PEG) 4000 in invitro and invivo experiments. In vitro rumen gas production values at $24 \mathrm{~h}$ were 58.67, 55.0 and $61.67 \mathrm{ml} / 400 \mathrm{mg}$ for CFM1, CFM2 (15\% mesquite pods) and CFM3(15\% mesquite pods $+4 \%$ PEG4000) respectively. Dry matter digestibility (DMD \%) was 63.58, 64.50 and $66.65 \%$ for CFM1, CFM2 and CFM3, respectively. In vivo experiment was done using 15 growing goat kids $(10.49 \pm 1.29 \mathrm{Kg})$ which were randomly divided into three groups. Group one (G1) was fed on concentrate feed mixture (CFM) and pasture (desert grass, Panicumtidrgium), group two (G2) was fed on CFM with 15\% ground mesquite pods and pasture and group three (G3) was fed on with 15\% ground mesquite pods plus 4\% PEG 4000. Using PEG 4000 in G3 resulted in increasing intake from pasture by 19.45 and $30.51 \%$ from pasture intake in G1 and G2, respectively. Digestibility coefficients were very close to each other's. Values of NDF and ADF digestibility tended to increase in mesquite pods groups (G2 and G3) compared to control group (G1). Also, TDN\% values were 74.46, 77.69 and 77.68\% for G1, G2, and G3, respectively. Using PEG 4000 (G3) with mesquite pods had the best values over all groups in average daily gain (60.13 g/day),body weight gain $(9.02 \mathrm{Kg})$ and final body weight $(19.5 \mathrm{Kg})$.Serum parameters were under normal range of healthy goats. In general, using mesquite pods decreased feed cost per day by about $21 \%$ from control diet and PEG group as well.
\end{abstract}

Keywords-Mesquite pods, Polyethylene glycol4000, Kids, digestibility, body weight, Shrub encroachment.

\section{INTRODUCTION}

Despite their robust growth and their high ability to adapt to harsh conditions in a wide range of environments around the world, invasive mesquite trees (Prosopisspp) represent a tangible threat to the sustainability of natural resources in rangelands and cultivated lands in many countries of the world. Mesquite (Prosiopsjoulifrolra) is an evergreen, nitrogen-fixing and xerophyte tree with many advantages like, fast growth, drought tolerance, Sand dune stabilization, sources of feeds (leaves and pods), offering shelters for wildlife, fire woods and coals. But also has disadvantages like highly competitive growth with other plant species (by allelopathic effects) which reduce the plant biodiversity, consume water resources in arid and semi-arid regions, leaves are less to unpalatable (except for camels) due to thorns and high anti- nutritional factors (like tannins) in the leaves, meanwhile dry matter intake maybe reduced when animals fed on diet consisted of $20 \%$ or more of mesquite 
pods and pods maybe toxic for livestock if it was consumed up to $50 \%$ of diet (Sawal et al., 2004, Mahgoub et al., 2005; Shackleton et al., 2014; and Patnaik et al 2017). From Central America mesquite trees are invading many places in the world as well as Africa, Asia and Australia (Shackleton et al., 2014 and Patnaik et al 2017).

Several studies reported that shrub encroachment like mesquite in some Arab countriessuch Sudan, Egypt, Saudi Arabia, Somalia, Oman, and Yemen which resulted in negative impact on rangeland heath and productivity. Mesquite encroachment had negativity impacted the rangelands condition in southeastern Egypt, whereas areas with high mesquite cover were associated with lower Panicumturgidum coverage (Mohamed, et al., 2015; Mohamed, 2019). The area of lands that were invaded by Mesquite in Tokar Delta in eastern Sudan was estimated at 297 thousand acres out of the total area of Tokar Delta, which is estimated at 406 thousand acres. In a recent study (Nzumira, 2014) to assess the changes occurring in the vegetation cover of mesquite trees and the extent of their invasion of the Gash delta lands in eastern Sudan, it was found that the mesquite trees covered an area of 142 thousand hectares of the total area of the Gash Delta, which is estimated at about 372 thousand hectares in the period between year 1979 and 2013.

Many efforts were done in infected areas around the world to control mesquite trees widespread using physical (by firing), mechanical (by removing), chemical (pesticides) and biological (by introducing insects) control (Patnaik et al 2017 and Zimmermann 1991) but all these methods have many disadvantages that make them unsustainable approach for examples mechanical methods are laborious and expensive, chemical method can be source of environmental pollution and affect non target organisms and finally biological method by introducing new organism into new habitat it can turned itself into new bio-invasion (like what was happened in Austuralia).In south eastern part of Egypt (Halaib and Shalateen region) our team reported increasing in mesquite trees populations in from 2002 to 2012 by using high resolution satellite imagery (Mohamed et al., 2015). According to Makkar et al., (1990) mesquite pods have high nutritive value (77\% TDN and 11-17 CP\%). Unfortunately the main source of widespread of seeds is range animals (cows, camels, sheep and goats) which feed on mesquite pods and excrete seeds in feces which can grow easily after that (Sawal et al., 2004 and Shackleton et al., 2014). But, collecting and grinding (so destroying seed germination ability) of mesquite pods that can break the life cycle of mesquite trees and reduce future widespread by sustainable method. Also usingcollected mesquite pods as animal feed can reduce feed cost (Sawal et al., 2004) and reducing unemployment that maybe will be source of income and enhance livelihood of poor farmers in arid regions.

Experience has shown that the mesquite extermination programs achieve temporary success, as soon as it fades away and the mesquite trees re-spread again, so presenting an integrated management program for mesquite trees in the Arab world is of importance in achieving sustainable development for the Arab countries that have been negatively affected by the invasion of mesquite and those that exhibit the spread of mesquite in those countries. This program should include a mixture between sustainable control methods and the economic adaptation of mesquite trees to become a source of additional income for farmers and herders.So, this study is aimed to investigate the responses of growing goats' kids when feeding on ground mesquite pods as part of concentrate portion of diet using in vitro and in vivo tools.

\section{MATERIALS AND METHODS}

\section{Study Location:}

This study was carried out at Shalateen Research Station Desert Research Center (DRC), Ministry of Agriculture and Land Reclamation, at RasHadraba valley- Halaib regionRed Sea Governorate, (about 1400 km southeast of Cairo), Egypt.

The region is located at longitudes $\left(36^{\circ}, 52^{\prime}, 676^{\prime \prime} \& 36^{\circ}\right.$, $\left.45^{\prime}, 002^{\prime \prime}\right)$ and latitudes $\left(21^{\circ}, 59^{\prime}, 795^{\prime \prime} \& 22^{\circ}, 59^{\prime}, 992^{\prime \prime}\right)$. It is classified as an arid region with average ambient air temperatures are $35^{\circ} \mathrm{C}$ and $22^{\circ} \mathrm{C}$, and relative humidity values are $37 \%$ and $43 \%$ for the summer and winter seasons, respectively. The average annual precipitation is about 58.5 $\mathrm{mm}$, and mostly as erratic showers in November and December. Water resources are scarcity and available only too nomadic inhabitants and their animals from shallow wells and desalination Seawater. Thus, agricultural activities are absent and livestock (sheep, goats and camels) grazing on rangelands is considered the only option of livelihood for the farmers(Askar et al., 2014;Nassar, 2020).According to Badawy (2005),Allam et al. (2007) and Raef (2012)desert grass (Panicumturgidum) is the main dominant pasture grass with abundance $(95.9 \%$ and $97.7 \%)$ and plant density $(0.455$ and $0.296 \mathrm{plant} / \mathrm{m}^{2}$ ) for wet and dry seasons, respectively. The dry biomass yield of $P$. turgidum was 1.46 Ton/feddan 
$\left(4200 \mathrm{~m}^{2}\right)$ in the wet season and $1.25 \mathrm{Ton} /$ feddan in the dry season, respectively.

\section{Mesquite pods collection and Preparation}

Air dried full mature mesquite pods were collected from around mesquite trees - Halaib and Shalateen region - by hands and stored under indirect sun cured and well ventilated shade. Then ground into fine powder and well mixed with other feed ingredients to make three different combinations of concentrate feed mixtures as shown in Table(1):

Table.1: Composition of concentrate feed mixtures $(\mathrm{kg} / 100$ $\mathrm{kg})$

\begin{tabular}{|l|c|c|c|}
\hline Ingredient composition & CFM1 & CFM2 & CFM3 \\
\hline Yellow corn & 42 & 41 & 41 \\
\hline Undecorticated cotton & 30 & 30 & 30 \\
\hline Wheat bran (coarse) & 24.5 & 10.5 & 10.5 \\
\hline Mesquite pods & 0 & 15 & 15 \\
\hline lime stone & 2 & 2 & 2 \\
\hline Common salt & 1 & 1 & 1 \\
\hline Trace minerals \& & 0.5 & 0.5 & 0.5 \\
\hline + PEG 4000 & 0 & 0 & 4 \\
\hline
\end{tabular}

- CFM1: Concentrate feed mixture

- CFM2: Concentrate feed mixture included 15\% crushed mesquite pods

- CFM3: Concentrate feed mixture included15\% crushed mesquite pods $+4 \%$ PEG 4000

\section{In vitro experiments}

In vitro gas production was carried out according to Menke and Steingass (1988). Two healthy adult fistulatedBarki rams were fed on good quality Egyptian clover hay (60\%) and concentrate feed mixture (40\%) which were used as a source of rumen liquor which. Finely ground(Approximately 400mg, air dried) concentrates samples (CFM1, CFM2 and CFM3) were accurately weighted into glass bottle then incubated with buffered rumen liquor for $48 \mathrm{~h}$ and incubated anaerobically at $39^{\circ} \mathrm{C}$. Total gas production was measured at 24 and $48 \mathrm{~h}$. Then $\mathrm{pH}$ was measured immediately using digital $\mathrm{pH}$ meter. Ammonia and, total volatile fatty acids (TVF's), in vitro dry matter (DM), neutral detergent fiber(NDF) and acid detergent fiber (ADF) digestibility were determined.

Organic matter digestibility (OMD), Metabolisable energy (ME) and total digestible nutrients (TDN) were calculated from the amount of gas produced at $24 \mathrm{hrs}$ of incubation with the components of feeds from crude protein (CP), ether extract (EE ) and total ash (TA) according Menke and Steingass (1988) for concentrate samples.

$-\underset{0.0181 \mathrm{TA}(\mathrm{g} / \mathrm{kg})}{\mathrm{OMD}}=9+\quad 0.9991 \mathrm{GP}+\quad 0.0595 \mathrm{CP}(\mathrm{g} / \mathrm{kg})+$

$-\mathrm{ME}(\mathrm{MJ} / \mathrm{kgDM})=1.06+0.1570 \mathrm{GP}+0.0084 \mathrm{CP}(\mathrm{g} / \mathrm{kg})+$ $0.022 \mathrm{EE}(\mathrm{g} / \mathrm{kg})-0.0081 \mathrm{TA}(\mathrm{g} / \mathrm{kg})$

$-\operatorname{TDN}(\%)=[\mathrm{ME}(\mathrm{MCal} / \mathrm{kg} \mathrm{DM})+0.45] / 0.0445309$ (NRC, 1989)

\section{In vivo experiment}

Fifteen growing male Blady goat kids $(10.49 \pm 1.29 \mathrm{Kg})$ were used in the feeding trail for five months divided on randomly basis into three groups (five animals per each group). Before commencing the trial all animal were drenching against internal parasites, animals fed on CFM by $3 \%$ of live body weight according NRC (1981) and allow daily to graze desert grass (Panicumturgidum). Animals were weighted biweekly and concentrate feeds were adjusted according animal body weight. Drinking water was available three times per day. Mineral blocks were freely available.

\section{Digestibility trials and determine pasture dry matter intake:}

Fecal collection bags were used to quantitative collection of feces from each animal daily for five days. Fecal bags were emptied daily weighted and $10 \%$ samples were taken and dried at $65^{\circ} \mathrm{C}$ for a constant weight. The pasture intake and digestibility were determined using the acid insoluble ash (AIA) method as internal marker (Schneider and Flatt (1975). Using the following equations:

- Marker in pasture $=$ Marker in feces - Marker in concentrate diet.

[Total marker in range intake per day]

- Estimated DMI $(\mathrm{gm} /$ day $)=$

[Concentration of marker in range dry basis]

\section{Analytical procedures}

Proximate analysis for dry matter (DM), crude protein (CP), crude fiber (CF), ether extract (EE) were determined according to the official methods (AOAC, 1990). Neutral detergent fiber (NDF) and acid detergent fiber (ADF) were estimated according to Van Soest and Robertson (1985). Acid insoluble ash (AIA) was analyzed according to Van Keulen and Young (1977). Total volatile fatty acids (TVFA's) were by steam distillation determined according to Annison (1954), Ammonia was determined concentration was carried out by a modified Nessler's method modified by 
Szumacher-Strabelet al., (2002). Total tannins (TT) were determined gravimetrically with copper acetate method according to Balbaa (1986). Condensed tannins (CT) were determined by spectrophotometer according to Makkaret al. (2007). TT and CT were determined only for mesquite pods.

Blood samples were collected from the jugular vein before morning feeding and were allowed to stand at room temperature for $1 \mathrm{~h}$ then centrifuged at $3000 \mathrm{rpm}$ for $20 \mathrm{~min}$ to get serum then and stored at $-20{ }^{\circ} \mathrm{C}$ for further analysis of blood metabolites using colorimetric methods as follows: Total protein and albumin were measured according to Gornal et al. (1949) and Doumas et al. (1971), respectively and globulin was determined by the difference (TP-Alb). Blood urea nitrogen (BUN) was determined according to Fawcett and Soctt (1960). Blood serum creatinine was determined according to Bartles et al. (1972) and Larsen (1972)

\section{Statistical analysis}

Data Differences among treatments were significantly checked using one way analysis of variance (ANOVA) and Duncan's new multiple range test (Duncan, 1955) was used to compare between means. The relationships between in vitro parameters were checked for simple correlation. The General Linear Model (GLM) of SAS (1996) was applied.

\section{RESULTS AND DISCUSSIONS}

\section{Chemical compositions of experimental feeds:}

Chemical composition of ground mesquite pods (Prosopisjuliflora), concentrate feed mixtures and desert grass (Panicumturgidum) are shown in Table (2). Mesquite pods chemical composition of $\mathrm{CP}, \mathrm{CF}$ and $\mathrm{EE}$ was 18.8 , 20.39 and $4.07 \%$, respectively. Which is comparable with Sawal et al (2004) who reported that the range of CP (11.99 - 16.5\%), CF (16.9-30.77\%), EE (1.3 - 4.26). Differences in Mesquite pods chemical composition maybe due to different environmental factors (soil type, water viability, temperature) and plant varieties. In current study replacing wheat bran in concentrate feed mixtures with mesquite pods at $15 \%$ didn't make differences on chemical compositions (Table 2) and the concentrate combinations are iso-caloric $(18.46,18.92$ and $18.89 \mathrm{MJ} / \mathrm{Kg} \mathrm{DM})$ andiso-nitrogenous CP (17.42, 17.79 and 17.39\%) for CFM1, CFM2 and CFM3, respectively.

Table.2: Chemical composition of experimental feeds (\%, DM basis)

\begin{tabular}{|l|c|c|c|c|c|}
\hline Item & Mesquite Pods & CFM1 & CFM2 & CFM3 & Desert grass \\
\hline DM & 91.56 & 91.28 & 91.88 & 91.53 & 37.96 \\
\hline OM & 95.17 & 92.52 & 93.56 & 93.34 & 92.74 \\
\hline Ash & 4.83 & 7.48 & 6.44 & 6.66 & 7.26 \\
\hline CP & 18.80 & 17.42 & 17.79 & 17.39 & 7.72 \\
\hline CF & 20.39 & 7.05 & 8.43 & 7.84 & 33.58 \\
\hline EE & 4.07 & 4.98 & 6.15 & 6.28 & 3.54 \\
\hline NFE & 51.92 & 63.07 & 61.18 & 61.81 & 47.91 \\
\hline NDF & 48.9 & 34.61 & 36.83 & 35.82 & 74.78 \\
\hline ADF & 33.68 & 15.9 & 18.32 & 17.11 & 42.37 \\
\hline GE (MJ/Kg DM)* & 18.82 & 18.46 & 18.92 & 18.89 & 17.57 \\
\hline
\end{tabular}

* Mesquite pods (Prosopisjuliflora)

*CFM1: Concentrate feed mixture

* CFM2: Concentrate feed mixture included $15 \%$ ground mesquite pods

*CFM3: Concentrate feed mixture included $15 \%$ ground mesquite pods + 4\% PEG 4000

*Desert grass (Panicumturgidum)

$* \mathrm{GE}=0.0176 \mathrm{OM}+0.0064 \mathrm{CP}+0.0214 \mathrm{EE}$ according to SCA (1990)

$* \mathrm{GE}(\mathrm{MJ} / \mathrm{KgDM})=0.0176 \mathrm{OM}(\mathrm{g} / \mathrm{kg})+0.0064 \mathrm{CP}(\mathrm{g} / \mathrm{kg})+0.0214 \mathrm{EE}(\mathrm{g} / \mathrm{kg})$ according to SCA (1990)

\section{In vitro experiment}

In vitro gas production parameters are shown in Table (3) and correlation coefficient of gas production parameters are shown in Table (4). In general, CFM2 with $15 \%$ ground mesquite pods had the lowest values in all gas production parameters estimated and calculated and this can be explained by the presence total tannins (TT) and condensed tannins (CT) in mesquite pods (1.64 and $0.83 \%$, 
respectively). But, with little small effects on DMD\% being $63.58,64.50$ and $66.65 \%$ and on NDF\% as $45.32,42.92$ and $44.61 \%$ for CFM1, CFM2 and CFM3, respectively(Table 3).

Polyethylene glycol (a synthetic polymer) has higher affinity to tannins more than protein. It disrupts tannin-protein complexes and increases protein availability for rumen microflora and then to the host animal. The PEG has positive effects like increase feed intake, digestibility, and live weight gain in animals fed on tannin-rich diets. On other hand PEG had negative effects like very expensive especially in developing countries and it may reduce the effect of tannin on decreasing methane production and internal parasites (Makkar et al., 1995; Kabasa et al., 2000; Ben Salem et al., 2005, Bhatta et al., 2009 and Ghandour et al., 2014).

Using PEG 4000 as feed additives in CFM3 enhanced total gas production in 24 and $48 \mathrm{~h}$ by 12.13 and $8.11 \%$ of CFM2, respectively. But this addition just increased DMD\% with $3.33 \%$ over mesquite pods without PEG (CFM2). In the same direction Guerrero et al., (2012) found that in in vitro study that PEG supplementation of Acacia constricta shrub with low $\mathrm{CT}(0.3 \%)$ that increased significantly gas production from 137 to $207 \mathrm{ml} 24 \mathrm{~h}$, but with small little increase in DMD 54.6 to $57.9 \%$ non-significant. This results agreed with Bayssa et al., (2016) who reported very high values of phenolic compounds in mesquite pods for example TT was $14.1 \%$ and CT was $7.2 \%$ and they found increasing in OMD\% (from 48 to $57.8 \%$ ), $\mathrm{ME}$ from (6.2 to $9.9 \mathrm{MJ} / \mathrm{Kg}$ ) and TVFA (from 0.63 to $0.92 \mathrm{mmol} / \mathrm{L}$ ) in mesquite pods and mesquite pods treated with $2 \%$ PEG solution, respectively. On contrary Makkar et al., (1990) reported values of mesquite pods had TT (2.92\%) and CT (0.68\%) (whichsimilar to current study) and not detected value of Protein-Perceptible phenolics (was), not detected Protein precipitation capacity, Degree of polymerisation (DP) was 2.33 , that indicated low activity of mesquite pods tannins. In the same trend Hanafy et al., (2015) reported that in vitro gas production (24h) values of Acacia slignashrub that had high TT (6.66\%) and CT (4.69\%) were 22.0 and 17.8 $\mathrm{ml} / 200 \mathrm{mg}$ for acacia without and with 4\%PEG 4000, respectively.

The values of ADFD\% (Table 3) were 55.13, 46.98 and $59.01 \%$ for CFM1, CFM2, CFM3, respectively. Decreasing $\mathrm{ADFD} \%$ in CFM2 may be explained by the lowest rumen microbe fermentation as reflected the lowest gas production at 24 and $48 \mathrm{~h}$ and TVFA's concentration (table 3). That supported by strong correlation coefficient (with highly statistically significance) between ADFD\% and TG24, TG48, pH (Table 4). Santos et al., (2015) reported low
ADFD\% being 42.2 to $33.4 \%$ when replacing mesquite pods from total diet by 0 to 15 in sheep (in vivo). Obeidat and Shdaifat (2013) also reported decreasing in ADFD\% with linearity increasing of mesquite pods in lactatingAwasssi ewes' diet from $0,12.5$ and $25 \%$.

Table.3: Rumen in vitro gas production and nutritive value of different concentrate feed mixtures.

\begin{tabular}{|l|c|c|c|c|}
\hline Item & CFM1 & CFM1 & CFM1 & \pm SE \\
\hline TG24, ml & $58.67^{\mathrm{b}}$ & $55.00^{\mathrm{c}}$ & $61.67^{\mathrm{a}}$ & 1.10 \\
\hline TG48, ml & $75.00^{\mathrm{b}}$ & $74.00^{\mathrm{b}}$ & $80.00^{\mathrm{a}}$ & 0.97 \\
\hline $\mathrm{pH}$ & $6.48^{\mathrm{b}}$ & $6.56^{\mathrm{a}}$ & $6.41^{\mathrm{b}}$ & 0.02 \\
\hline NH3-N, (mg/100 ml) & 24.78 & 20.70 & 21.60 & 1.32 \\
\hline $\begin{array}{l}\text { TVFA's } \\
\text { (m.equiv./100 ml) }\end{array}$ & 4.096 & 3.421 & 3.570 & 0.22 \\
\hline DMD\% & $63.58^{\mathrm{b}}$ & $64.50^{\mathrm{ab}}$ & $66.65^{\mathrm{a}}$ & 0.61 \\
\hline OMD\% & $79.33^{\mathrm{a}}$ & $75.70^{\mathrm{b}}$ & $82.17^{\mathrm{a}}$ & 1.03 \\
\hline NDFD\% & 45.32 & 42.92 & 44.61 & 0.80 \\
\hline ADFD\% & $55.13^{\mathrm{b}}$ & $46.98^{\mathrm{c}}$ & $59.01^{\mathrm{a}}$ & 1.77 \\
\hline ME, ( MJ/DM kg) & $12.22^{\mathrm{b}}$ & $12.02^{\mathrm{b}}$ & $13.05^{\mathrm{a}}$ & 0.17 \\
\hline TDN\% & $75.71^{\mathrm{b}}$ & $74.63^{\mathrm{b}}$ & $80.12^{\mathrm{a}}$ & 0.92 \\
\hline
\end{tabular}

*CFM1: Concentrate feed mixture

* CFM2: Concentrate feed mixture included $15 \%$ ground mesquite pods

*CFM3: Concentrate feed mixture included $15 \%$ ground mesquite pods $+4 \%$ PEG 4000

$\mathrm{ME}=1.06+0.1570 \mathrm{GP}+0.0084 \mathrm{CP}+0.022 \mathrm{EE}-0.0081 \mathrm{TA}$

$\mathrm{OMD} \%=9+0.9991 \mathrm{GP}+0.0595 \mathrm{CP}+0.0181 \mathrm{TA}$

$\mathrm{TDN}(\%)=[\mathrm{ME}(\mathrm{MCal} / \mathrm{kg} \mathrm{DM})+0.45] / 0.0445309$

\section{In vivo experiment}

\section{Feed intake}

Inclusion ground mesquite pods by $15 \%$ from concentrate diet and replaced mainly from wheat bran (Table 1,2) that resulted in iso-caloric (18.46, 18.92 and $18.89 \mathrm{MJ} / \mathrm{Kg} \mathrm{DM})$ and iso-nitrogenous CP (17.42, 17. 79 and 17.39\%) for, CFM1, CFM2 and CFM3, respectively (Table 2). Dry matter intake from concentrate, forage and total intake are shown in Table (5). Average dry matter intake from concentrate feed mixtures (CFM) were 27.38, 27.56 and $27.46 \mathrm{~g} / \mathrm{kg}$ BW for G1, G2 and G3 groups, respectively. Without any adverse effects of mesquite pods and prove that mesquite pods was palatable at this level of replacement. 
Average dry matter intake from forage, desert grass (Panicumturgidum), was 233.14, 213.38 and $278.48 \mathrm{~g} /$ day for G1, G2 and G3 groups, respectively. Using PEG 4000 in G3 resulted in increasing intake from pasture (by 19.45 and $30.51 \%$ from pasture intake in G1 and G2, respectively). That may be explained by presence of some phenolic compounds like total phenolics, flavonoids and tannins in desert grass as reported by Farag et al., (2016) and Al-
Rowaily et al., (2019) but with low concentrations. Also Khan et al., (2009) reported total oxalate reached $4.14 \%$ in Panicumturgidum. This compound may be decrease feed intake by unpleasant taste (bitter and/or astringent taste). However, Ghandour (2014) reported enhancing DMI in sheep fed on plant rich tannins (Acicia hay) by using PEG 4000 .

Table 4: Correlation coefficients of Gas production parameters

\begin{tabular}{|c|c|c|c|c|c|c|c|c|c|c|c|}
\hline Item & TG24 & TG48 & $\mathrm{pH}$ & NH3 & VFA & ME & TDN & DMD & OMD & NDFD & ADFD \\
\hline TG24 & 1.00 & $\begin{array}{l}0.86 \\
* *\end{array}$ & $\begin{array}{l}-0.93 \\
* * *\end{array}$ & $\begin{array}{l}0.45 \\
\mathrm{~ns}\end{array}$ & $\begin{array}{l}0.45 \\
\text { Ns }\end{array}$ & $\begin{array}{l}0.94 \\
* * *\end{array}$ & $\begin{array}{l}0.94 \\
* * *\end{array}$ & $\begin{array}{l}0.35 \\
\text { Ns }\end{array}$ & $\begin{array}{l}0.99 \\
* * * *\end{array}$ & $\begin{array}{l}0.41 \\
\text { Ns }\end{array}$ & $\begin{array}{l}0.90 \\
* *\end{array}$ \\
\hline TG48 & & 1.000 & $\begin{array}{l}-0.84 \\
* *\end{array}$ & $\begin{array}{l}0.13 \\
\mathrm{~ns}\end{array}$ & $\begin{array}{l}0.14 \\
\text { Ns }\end{array}$ & $\begin{array}{l}0.94 \\
* * *\end{array}$ & $\begin{array}{l}0.94 \\
* * *\end{array}$ & $\begin{array}{l}0.61 \\
n s\end{array}$ & $\begin{array}{l}0.85 \\
* *\end{array}$ & $\begin{array}{l}0.27 \\
\mathrm{Ns}\end{array}$ & $\begin{array}{l}0.92 \\
* * *\end{array}$ \\
\hline $\mathrm{pH}$ & & & 1.00 & $\begin{array}{c}-0.54 \\
\mathrm{~ns}\end{array}$ & $\begin{array}{c}-0.54 \\
\text { Ns }\end{array}$ & $\begin{array}{c}-0.88 \\
* *\end{array}$ & $\begin{array}{l}-0.88 \\
* *\end{array}$ & $\begin{array}{l}-0.50 \\
\mathrm{~ns}\end{array}$ & $\begin{array}{l}-0.93 \\
* * *\end{array}$ & $\begin{array}{l}-0.31 \\
\mathrm{Ns}\end{array}$ & $\begin{array}{l}-0.91 \\
* * *\end{array}$ \\
\hline NH3 & & & & 1.00 & $\begin{array}{l}0.99 \\
* * * *\end{array}$ & $\begin{array}{l}0.24 \\
\mathrm{~ns}\end{array}$ & $\begin{array}{l}0.24 \\
\text { Ns }\end{array}$ & $\begin{array}{l}-0.29 \\
\mathrm{~ns}\end{array}$ & $\begin{array}{l}0.46 \\
\mathrm{~ns}\end{array}$ & $\begin{array}{l}0.68 \\
\text { ns }\end{array}$ & $\begin{array}{l}0.35 \\
\mathrm{~ns}\end{array}$ \\
\hline VFA & & & & & 1.00 & $\begin{array}{l}0.25 \\
\mathrm{~ns}\end{array}$ & $\begin{array}{l}0.24 \\
\text { Ns }\end{array}$ & $\begin{array}{l}-0.29 \\
\mathrm{~ns}\end{array}$ & $\begin{array}{l}0.46 \\
\mathrm{~ns}\end{array}$ & $\begin{array}{l}0.68 \\
*\end{array}$ & $\begin{array}{l}0.35 \\
\mathrm{~ns}\end{array}$ \\
\hline ME & & & & & & 1.00 & $\begin{array}{l}0.999 \\
* * * *\end{array}$ & $\begin{array}{l}0.52 \\
\mathrm{~ns}\end{array}$ & $\begin{array}{l}0.93 \\
* * *\end{array}$ & $\begin{array}{l}0.28 \\
\text { Ns }\end{array}$ & $\begin{array}{l}0.90 \\
* * *\end{array}$ \\
\hline TDN & & & & & & & 1.00 & $\begin{array}{l}0.53 \\
\text { Ns }\end{array}$ & $\begin{array}{l}0.93 \\
* * *\end{array}$ & $\begin{array}{l}0.29 \\
\text { Ns }\end{array}$ & $\begin{array}{l}0.90 \\
* * *\end{array}$ \\
\hline DMD & & & & & & & & 1.00 & $\begin{array}{l}0.34 \\
\mathrm{~ns}\end{array}$ & $\begin{array}{l}-0.49 \\
\text { Ns }\end{array}$ & $\begin{array}{l}0.53 \\
\mathrm{~ns}\end{array}$ \\
\hline OMD & & & & & & & & & 1.00 & $\begin{array}{l}0.42 \\
\mathrm{Ns}\end{array}$ & $\begin{array}{l}0.89 \\
*\end{array}$ \\
\hline NDFD & & & & & & & & & & 1.00 & $\begin{array}{l}0.34 \\
\text { ns }\end{array}$ \\
\hline ADFD & & & & & & & & & & & 1.00 \\
\hline
\end{tabular}

Average total DMI was $733.69,708.43$ and $822.72 \mathrm{~g} /$ day for G1, G2 and G3, respectively. Calculated mesquite pods percentage from total diet in current study were $14.05 \%$ from G2 and $14.15 \%$ from G3 that level didn't induce negative effects on feed intake which started to decrease feed intake may be at $20 \%$ inclusion as reported by Obeidatand Shdaifat (2013) who also reported that replacement mesquite pods in lactating Awasssi ewes' diet from 0 to $12.5 \%$ didn't affect
DMI but when increasing the percentage of replacement to $25 \%$ then TDMI decreased by 2.36 and $2.6 \%$ of 0 to $12.5 \%$ mesquite pods replacement groups, respectively. Similar finding was observed for $\mathrm{OM}, \mathrm{CP}$ and fibre fraction (NDF and $\mathrm{ADF}$ ) intakes, it can notice that, kids in G3 group had higher intake from $\mathrm{OM}, \mathrm{CP}, \mathrm{NDF}$ and $\mathrm{ADF}$ than other groups, but, this increase was insignificantly. 
Table.5: Effect of treatments on feed intake by kids during digestibility trial.

\begin{tabular}{|c|c|c|c|c|}
\hline Item & G1 & $\mathrm{G} 2$ & G3 & $\pm \mathrm{SE}$ \\
\hline No of animal & 5 & 5 & 5 & - \\
\hline Body weight,kg & 18.28 & 17.96 & 19.82 & 0.70 \\
\hline \multicolumn{5}{|l|}{ Dry matter intake, } \\
\hline \multicolumn{5}{|l|}{ Concentrate intake, } \\
\hline g/day & 500.56 & 495.06 & 544.24 & 19.17 \\
\hline $\mathrm{g} / \mathrm{Kg} \mathrm{BW}$ & 27.38 & 27.56 & 27.46 & 0.02 \\
\hline \multicolumn{5}{|l|}{ Forage intake, } \\
\hline g/ day & 233.14 & 213.38 & 278.48 & 21.96 \\
\hline $\mathrm{g} / \mathrm{Kg} \mathrm{BW}$ & 12.82 & 12.62 & 14.28 & 1.22 \\
\hline \multicolumn{5}{|l|}{ Total DM intake } \\
\hline g/day & 733.69 & 708.43 & 822.72 & 27.97 \\
\hline $\mathrm{g} / \mathrm{Kg} \mathrm{BW}$ & 40.21 & 40.18 & 41.74 & 1.22 \\
\hline \multicolumn{5}{|l|}{ Total OM intake, } \\
\hline g/day & 680.45 & 661.04 & 763.01 & 25.81 \\
\hline $\mathrm{g} / \mathrm{Kg} \mathrm{BW}$ & 37.29 & 37.49 & 38.71 & 0.11 \\
\hline \multicolumn{5}{|l|}{ Total CP intake, } \\
\hline g / day & 105.21 & 104.57 & 116.17 & 3.58 \\
\hline $\mathrm{g} / \mathrm{Kg} \mathrm{BW}$ & 5.76 & 5.88 & 5.88 & 0.09 \\
\hline \multicolumn{5}{|l|}{ Total NDF intake, } \\
\hline g / day & 347.59 & 341.89 & 403.19 & 17.18 \\
\hline $\mathrm{g} / \mathrm{Kg} \mathrm{BW}$ & 19.07 & 19.59 & 20.52 & 0.92 \\
\hline \multicolumn{5}{|l|}{ Total ADF intake, } \\
\hline g / day & 178.36 & 181.12 & 211.11 & 9.52 \\
\hline $\mathrm{g} / \mathrm{Kg} \mathrm{BW}$ & 9.79 & 10.40 & 10.75 & 0.52 \\
\hline
\end{tabular}

*G1: Concentrate feed mixture + Pasture

* G2: Concentrate feed mixture included $15 \%$ ground mesquite pods+ Pasture

$*$ G3: Concentrate feed mixture included $15 \%$ ground mesquite pods $+4 \%$ PEG $4000+$ Pasture

\section{Nutrients digestibility and nutritive value}

Nutrients digestibility and nutritive values are shown in the Table (6) most digestibility values closely similar in the three groups and the values statistically non-significant. But all values tended to increase in mesquite pods groups (G2 and G3) compared to control group (G1). This pattern was reflected on TDN\% values being 74.46, 77.69 and $77.68 \%$ for G1, G2, and G3, respectively. That indicate using mesquite pods at this level didn't have adverse effects on animal digestibility and nutritive value. In the same trend
Obeidat et al., (2008) found that similarity in DM, OM, CP, NDF and ADF among Awassi lambs groups with 0, 10 and $20 \%$ mesquite replacement. Obeidat and Shdaifat (2013) also reported that replacement mesquite pods in lactating Awasssi ewes' diet from 0 to $12.5 \%$ there were no effects on DM, $\mathrm{OM}, \mathrm{CP}$ and NDFD\% digestibility except decreasing in $\mathrm{ADFD} \%$ in mesquite (12.5\%) group. But when using increasing mesquite pods to $25 \%$ from the diet all digestibility parameters were dropped. 
Table.6: Nutrients digestibility and nutritive values of the experimental diets

\begin{tabular}{|c|c|c|c|c|}
\hline Item & G1 & G2 & G3 & \pm SE \\
\hline Digestibility, \% & & & & \\
\hline DM & 69.60 & 71.78 & 70.71 & 1.02 \\
\hline OM & 77.13 & 78.11 & 78.88 & 0.75 \\
\hline CP & 71.16 & 73.62 & 71.86 & 0.95 \\
\hline CF & 68.54 & 72.77 & 69.51 & 1.32 \\
\hline EE & 75.70 & 79.60 & 80.33 & 0.92 \\
\hline NFE & 79.03 & 79.55 & 81.07 & 1.00 \\
\hline NDF & 53.64 & 57.65 & 57.10 & 1.46 \\
\hline ADF & 42.10 & 46.81 & 45.95 & 1.68 \\
\hline TDN & & & & \\
\hline DCP & 74.64 & 77.69 & 77.68 & 0.87 \\
\hline Nutritive value, \% & 10.25 & 10.88 & 10.19 & 0.25 \\
\hline
\end{tabular}

*G1: Concentrate feed mixture + Pasture

* G2: Concentrate feed mixture included $15 \%$ ground mesquite pods+ Pasture

$* \mathrm{G} 3$ : Concentrate feed mixture included + 4\% PEG 4000+ Pasture

\section{Body weight changes}

Body weight changes through feeding period are illustrated in Fig. (1). It can be observed from the figure that goats consumed about one month as adaptation period (which means no changes in ADG). Same resulted was obtained by Mahgoub et al., (2005) who reported goats fed on 0, 10, 20 and $30 \%$ mesquite pods needed about one month to start gaining weight.

Initial, final body weight and average daily gain are shown in Table (7). Using mesquite pods (G2) had very close results of control group of final body weight, body weight gain and average daily gain as 18.6 and $18.5 \mathrm{Kg} ; 7.96$ and $8.16 \mathrm{Kg}$ and 53.10 and $54.4 \mathrm{~g} /$ day for $\mathrm{G} 1$ and $\mathrm{G} 2$, respectively. Meanwhile using PEG 4000 (G3) had the best values over all groups in final body weight $(19.5 \mathrm{Kg})$, body weight gain $(9.02 \mathrm{Kg})$ and average daily gain $(60.13 \mathrm{~g} /$ day $)$ which reflects high TDMI (Table 5) high TDN\% (Table 6). Shamseldein et al., (2013) reported that ADG of Sudanese Nubian goats kids was decreased by increasing mesquite pods gradually in the diet from $0,10,20$ to $30 \%$ to be $96.33,97.55,91.22$ and $73.06 \mathrm{~g} /$ day, respectively.

\section{Feed conversion and economic evaluation}

Feed conversionratios were 10.87, 10.77 and 9.60 $\mathrm{DMI} / \mathrm{kgBW}$ for G1, G2 and G3, respectively (Table 7). That in agreement with Mahgoub et al., (2005) when goats fed on $0,10,20$ and $30 \%$ mesquite pods for two months FCR values were $10.78,10.76,6.56$ and $13.86 \mathrm{DMI} / \mathrm{kgBW}$, respectively.

Economic evaluation indicators data are shown in Table (7). Using mesquite pods (G2) decreased the feed cost per day and cost of BWG per $\mathrm{Kg}$ dropped by $21.3 \%$ and $23.16 \%$ from control group (G1) and this due to low cost of mesquite pods. Meanwhile high price of PEG 4000 (G3) resulted in approximately equalization of feed cost per day and cost of BWG per Kg in G1 and G3. Sawal (2004) reported when replacing wheat bran with mesquite pods reduced feed cost of lamb feeding. Economic efficiency was the highest G2 (2.1) then G3 (1.7) and G1(1.6).That maybe support and encourage researchers to find out affordable alternative of imported PEG 4000 like bentonite clay (Ghandour 2014 and Hanafy et al 2014).

Table.7: Body weight changes, feed conversion and economic efficiency of goats fed on experimental diets. 


\begin{tabular}{|l|c|c|c|c|}
\hline Item & G1 & G2 & G3 & \pm SE \\
\hline Body weight changes : & & & & \\
\hline Initial BW, Kg & 10.64 & 10.34 & 10.48 & 0.33 \\
\hline Final BW, Kg & 18.6 & 18.5 & 19.5 & 0.65 \\
\hline Total gain, Kg & 7.96 & 8.16 & 9.02 & 0.55 \\
\hline Average daily gain, g & 53.10 & 54.40 & 60.13 & 3.65 \\
\hline Feed conversion ratio : & & & & \\
\hline Feed conversion ratio, Kg DMI/Kg BW & 10.87 & 10.77 & 9.60 & 0.78 \\
\hline FCR (kg TDN/Kg BW) & 8.23 & 8.30 & 7.45 & 0.62 \\
\hline FCR (kg DCP/Kg BW) & 1.11 & 1.14 & 0.98 & 0.10 \\
\hline Economic evaluating indicators : & & & & \\
\hline Feed cost/day * Egyptian Pounds & 2.02 & 1.59 & 2.1 & \\
\hline Total feed cost & 303 & 238.5 & 315 & \\
\hline Cost of one Kg BW gain & 38.04 & 29.23 & 34.92 & \\
\hline Price of total gain & 477.6 & 489.6 & 541.2 & \\
\hline Economic efficiency & 1.6 & 2.1 & 1.7 & \\
\hline
\end{tabular}

Economic efficiency (price of total body gain / cost of total feed consumed)

* feed cost/day is for concentrate and forage assumed to equal zero according to Nasser (2020) Economic indicators of feeds were calculated in Egyptian pound (EP) based on the price of the year 2020. The price per ton was assigned as follows; Ground mesquite pods $1000 \mathrm{EP}$; CFM $5000 \mathrm{EP}$; PEG $30000 \mathrm{EP}$, The price of kg live body weight at purchase or selling was $60 \mathrm{EP}$.

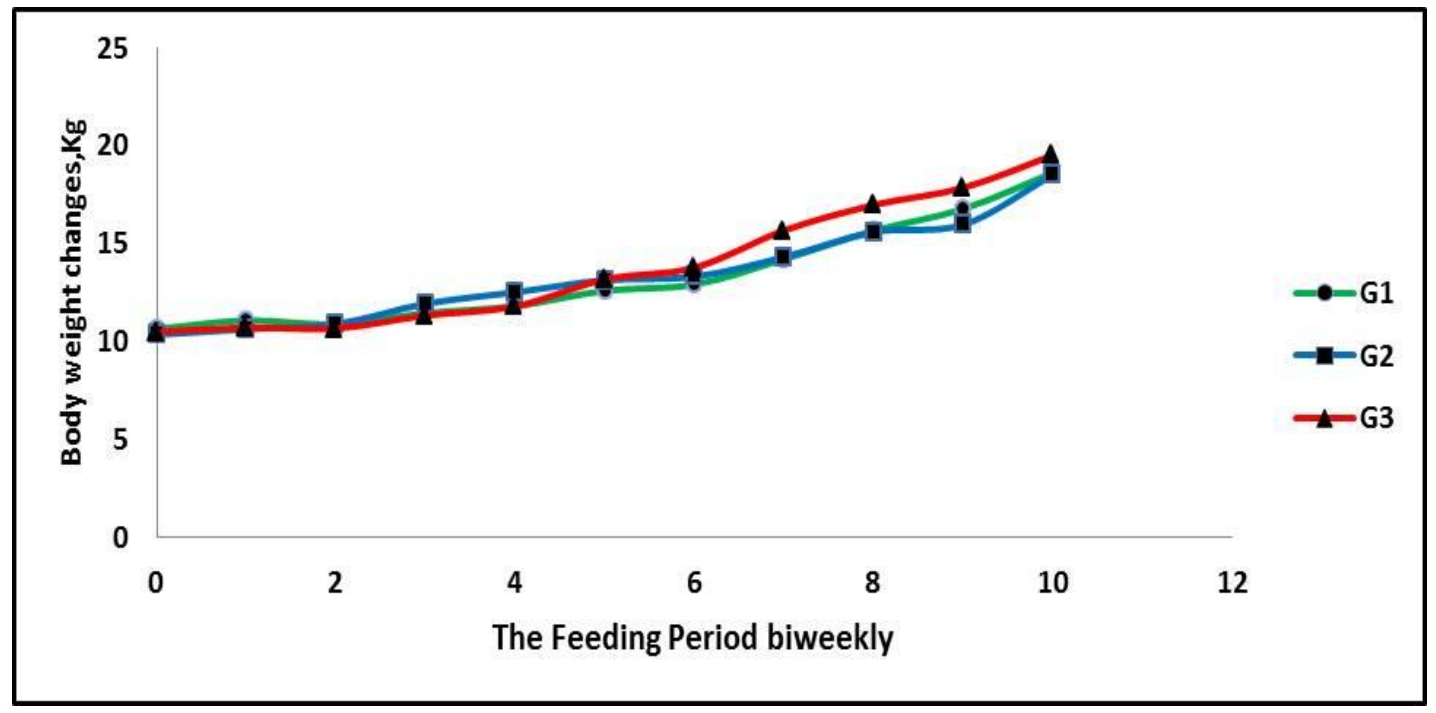

Fig.1: Body weight changes of growing goats during the feeding period

\section{Some blood metabolites}

Blood serum metabolites values of experimental goats are shown Table (8). All blood parameters were involved in the normal range of goats according to Jackson and Cockcroft (2002).That reflects safety level of mesquite pods were used in current study without any toxicity indicators in the blood serum parameters. In the same trend Chharan get al., (2020) reported that blood serum protein was 8.02 and $8.10 \mathrm{~g} / \mathrm{dl}$ and serum glucose was 72.00 and $69.75 \mathrm{mg} / \mathrm{dl}$ in growing goats fed on control diet or diet with $20 \%$ mesquite pods for 105 
days, respectively. Cook et al, (2008) reported closely results of serum metabolites like creatinine, blood urea nitrogen (BUN) Aspartate transaminase (AST) gamma glutamyl transferase (GGT) among goats fed on mesquite pods at $0,30,90 \%$ of the diet but for short period (14 days).

Table.8: Blood serum metabolites of goats fed the experimental diets.

\begin{tabular}{|l|c|c|c|c|c|}
\hline \multicolumn{1}{|c|}{ Item } & G1 & G2 & G3 & SE & Normal Range* \\
\hline $\mathrm{TP}(\mathrm{g} / \mathrm{dl})$ & 6.74 & 6.50 & 7.01 & 0.23 & $(6.0-7.9)$ \\
\hline $\mathrm{Al}(\mathrm{g} / \mathrm{dl})$ & 3.42 & 3.28 & 3.41 & 0.15 & $(2.9-4.3)$ \\
\hline $\mathrm{Glb}(\mathrm{g} / \mathrm{dl})$ & 3.32 & 3.21 & 3.61 & 0.27 & -- \\
\hline $\mathrm{Al} / \mathrm{Gl} \mathrm{ratio}$ & 1.22 & 1.26 & 1.23 & 0.15 & -- \\
\hline Creat & 0.92 & 0.88 & 0.75 & 0.10 & $(0.6-1.6)$ \\
\hline BUN(mg/dl) & 15.22 & 16.89 & 15.92 & 0.66 & $(12-26)$ \\
\hline Glucose $(\mathrm{mg} / \mathrm{dl})$ & 66.19 & 69.42 & 68.75 & 2.22 & $(50-75)$ \\
\hline
\end{tabular}

$*$ G1: Concentrate feed mixture + Pasture

* G2: Concentrate feed mixture included $15 \%$ ground mesquite pods+ Pasture

*G3: Concentrate feed mixture included $15 \%$ ground mesquite pods $+4 \%$ PEG 4000+ Pasture

\section{CONCLUSION}

It can be concluded that replacing wheat bran with mesquite pods at level $15 \%$ of concentre diet did not have any adverse effects on growing goat kids and it can reduce feed cost and increase economic efficiency of goat feeding under study conditions. There is need for further studies about how to reduce negative animals' responses to increase levels of mesquite pods up to $20 \%$ or more. Also there is a need to find out affordable alternative of PEG 4000 when using mesquite pods. These results could encourage small holders in desert areas to feed low cost Mesquite pods for goats, sheep and camels and reduce invasion of Mesquite trees at the same time.

\section{REFERENCES}

[1] Allam, S.M., Abou El-Nasr, H.M., Abd El-Gawad, M.H., Nassar, M.S., (2007). Performance of local goats maintained on natural ranges andsupplementary feeding in HalaibShalateen region. Egypt: 1. Does per-formance through pregnancy and lactation. Egyptian J. Nutr. Feeds 10,323-347

[2] Al-Rowaily, S. L., Abd-ElGawad A.M, Alghanem S.M.,. AlTaisan W. A., Yasser El-Amier, A. Y. (2019). Nutritional Value, Mineral Composition, Secondary Metabolites, and Antioxidant Activity of Some Wild Geophyte Sedges and Grasses. Plants.2019; 8(12): 569.

[3] Annison, E.F. (1954). Some observations on volatile fatty acids in sheep's rumen.Biochem. J., 57:400-405.
[4] AOAC (1990).Association of Official Analytical Chemists.Official Methods of Analysis. 15th Edition, Washington D.C., USA, 923pp

[5] Askar A R, Salama R, El-Shaer H M, Safwat M A, Poraei M, Nassar M S, Badawy H S, Raef O. (2014). Evaluation of the use of arid-area rangelands by grazing sheep: Effect of season and supplementary feeding. Small Ruminant Research, 121, 262-270

[6] Badawy, H.S.M., (2005). Nutritional studies on camels grazing the natural ranges of Halaib- shalateen triangle region. Ph.D. Thesis, Fac. Of Agric., Cairo Univ. Egypt 215pp

[7] Balbaa, S.I. (1986). Chemistry of Crude Drug.Laboratory Manual.Faculty of Pharmacy.Cairo University.195 p.

[8] Bartles, H.; Bohmer, M. and Heirli, C. (1972).Colorimetric kinetic method for creatinine determination in serum and urine.Clin. Chem. Acta, 37:193-197.

[9] Bayssa M., NegesseT.andTolera A.(2016) .Effect of Chemical and biological treatments on nutrient and phenolic composition in sacco degradability, invitro gas and methane production kinetics of Acacia tortilis and prosopisjuliflora leaves and pods. Middle-East Journal of Scientific Research 24(4): 1236-1251

[10] Ben Salem, H.; Saghrouni, L. and Nefzaoui A. (2005).Attempts to deactivate tannins in fodder shrubs with physical and chemical treatments. Anim. Feed Sci. Tech., 122:109-121.

[11] Bhatta, R.; Uyeno, Y.; Tajima, K.; Takenaka, A.; Yabumoto, Y.; Nonaka, I.; Enishi, O. and Kurihara, M. (2009). Difference in the nature of tannins on in vitro ruminal methane and volatile fatty acid production and on 
methanogenicarchaea and protozoal populations. J. Dairy Sci., 92:5512-5522.

[12] Chharang D., Sharma T., Karnani M., Manju and Kumar R. (2020) Effect of replacement of conventional feeds by Prosopisjuliflora pods and Citrulluslanatus seed cake on haemato-biochemical parameters in Marwari Goats Indian J. Anim. Nutr. 2020.37 (1): 21-25

[13] Cook, R. W.; Scott, C. B. and Hartmann, F. S. (2008). Shortterm Mesquite pod consumption by goats does not induce toxicity. Rangeland Ecology \& Management 61 (5): 566-570.

[14] Doumas, B.T.; Watson, W.A. and Biggs, H.G. (1971). Albumin standards and the measurement of serum albumin with bromocresol green. Clin.Chim.Acta, 31:87-96.

[15] Duncan, D.B. (1955). Multiple range and multiple F test. Biometric., 11:1-24.

[16] Farag, M. A., El Fishawy A.M., El-Toumy S.A., Amer, K.F., Mansour A.M., Taha H. E. (2016). Antihepatotoxic effect and metabolite profiling of Panicumturgidum extract via UPLCqTOF-MS. Pharmacognosy Magazine 12:446-453

[17] Fawcett, J. K. and Soctt J. E. (1960).A rapid and precise method for the determination of urea. J. Clinical Pathology, 13: 156-159.

[18] Ghandour, M. M. A.; Afaf M. Fayed; Abdul Aziz, G. M. and Hanafy, M. A. (2014) Effect of Using Polyethylene Glycol or Sodium Bentonite on Performance of Sheep Fed Acacia saligna. World Applied Sciences Journal, 32 (11): 2309-2316.

[19] Gornall, A.G., C.J. Bardawill and M.M. David, 1949.Formation of complexes between polyvinyl Determination of serum proteins by means of the pyrrolidones or polyethylene glycols and tannins biuret reaction. J. Biol. Chem., 177: 751-766.

[20] Guerrero, M., Cerrillo-Soto M.A., Ramírez R.G., Salem A.Z.M.,Gonz'alez H. and Juárez-Reyes A.S. (2012). Influence of polyethylene glycol on in vitro gas production profiles and microbial protein synthesis of some shrubspecies. Anim Feed Sci Technol. 176:32-39.

[21] Hanafy, M. A.; Abdul Aziz, G. M.; Afaf M. Fayed and Ghandour, M.M. (2014). In Vitro Evaluation of Using Tannins Deactivation Materials in Acacia saligna and Tamrixaphylla. Egyptian J. Nutrition and Feeds, 17 (1): 43-50.

[22] Jackson, P.G.G. and Cockcroft, P.D. (2002).Clinical Examination of Farm Animals.Blackwell Science Ltd. 313 p.

[23] Kabasa, J.D.; Opuda-Asibo, J. and Ter-Meulen, U. (2000). The effect of oral administration of polyethylene glycol on faecalhelminth egg counts in pregnant goats grazed on browse containing condensed tannins. Trop. Anim. Health Prod., 32:73-86.

[24] Khan, M. A., R. Ansari, H. Ali, B. Gul and B. L. Nielsen. 2009. Panicumturgidum: a sustainable feed alternative for cattle in saline areas. Agric. Ecosys. Environ. 129:542-546.

[25] Larsen, K. (1972). Creatinine assay by a reaction-kinetic approach.Clin. Chem. Acta, 41: 209-217.

[26] Mahgoub, O., Kadim, I. T., Forsberg, N. E., Al-Ajmi, D. S., Al-Saqry, N. M., Al-Abri, A. S., Annamalai, K., (2005).
Evaluation of Meskit (Prosopisjuliflora) pods as a feed for goats. Animal Feed Science and Technology, 121: 319-327.

[27] Makkar, H. P. S., B. Singh and S. S. Negi.(1990). Tannin levels and their degree of polymerization and specific activity in some agro-industrial by-products. Biological Wastes 31(2):137-144.

[28] Makkar, H.P.S.; Blummel, M. and Becker K. (1995).Formation of complexes between polyvinyl pyrrolidones or polyethylene glycols and tannins, and their implication in gas production and true digestibility in in vitro techniques. Br. J. Nutr., 73:897-913.

[29] Makkar, H.P.S.; Siddhuraju, P. and Becker, K. (2007).Plant Secondary Metabolites. Humana Press, USA, 130 p.

[30] Menke, K.H. and Steingass, H. (1988). Estimation of the energetic feed value obtained from chemical analyses and gas production using rumen fluid. Anim. Res. Develop., 28:7-55.

[31] Mohamed A. H. 2018. Using high spatial resolution satellite imagery to evaluate the impact of mesquite invasion on desert rangeland at southeastern Egypt. J. Bio. Env. Sci. 13(3), 167176.

[32] Mohamed A. H., El Shesheny M.A. , Hendawy S.H., Mahmoud H. S.(2015). Assessing Mesquite Cover Change in Southeastern Egypt using High Resolution Satellite Images. Current Science International 4(3): 351-357.

[33] Nassar, M.S. (2020) Effect of grazing time on productive performance of goat in Halaib - Shalateenregion.Egyptian J. Nutrition and Feeds 23 (1): 37-54

[34] NRC (1981). Nutrient Requirements of Goats: Angora, Dairy, and Meat Goats in Temperate and Tropical Countries. National Academy of Sciences, National Research Council. Washington, DC, 91pp.

[35] NRC (1989) Nutrient Requirements of Dairy Cattle. 6th revised edn.National Research Council, National Academy Press, Washington, DC

[36] Nzumira H.S (2014). Mesquite trees infestation of the Gash Spate Irrigation system in Kassala state, Sudan. Master thesis, UNESCO-IHE Institute for Water Education.

[37] ObeidatB. S., Shdaifat, M. M. (2013) Partial substitution of barley grain with Prosopisjuliflorapods in lactating Awassiewes' diets: effect on intake, digestibility, and nursing performance. Small Rumin Res 111:50-55

[38] Obeidat BS, Abdullah AY, Al-Lataifeh FA (2008) The effect ofpartial replacement of barley grains by Prosopisjuliflora pods on growth performance, nutrient intake, digestibility, and carcass characteristics of Awassi lambs fed finishingdiets. Anim Feed SciTechnol 146:42-54.

[39] Patnaik, P., T. Abbasi\& S. A. Abbasi. 2017. Prosopis (Prosopisjuliflora): blessing and bane. Tropical Ecology58: 455-483.

[40] Raef, O., 2012. Nutritive evaluation of natural ranges in the south easterncorner of Egypt. M. Sc. in Animal Nutrition, Faculty of Agriculture.Al-Azhar University, Cairo, Egypt.

[41] Santos, E., M. L. Pereira, P. J. Almeida, J. V. Moreira, A. C. Souza \& C. A. Pereira. (2015). Mesquite pod meal in sheep 
diet: intake, apparent digestibility of nutrients and nitrogen balance. ActaScientiarum. Animal Sciences 37: 55-59.

[42] SAS (1996).SAS (Statistical Analysis System) procedure guide.Version 6.12 edition. SAS institute, INC., Cary, NC, USA.

[43] Sawal, R. K., Ratan, R. and Yadav, S. B. S. (2004). Mesquite (Prosopisjuliflora) pods as a feed source for livestock: a review. Asian-Australian Journal of Animal Sciences,17, 719-25.

[44] Schneider, B.H and Flatt, W.P. (1975). The Evaluation of Feeds Through Digestibility Experiments. Univ. Georgia Press, Athens, USA.417 p.

[45] Shackleton RT, Le Maitre DC, Pasiecznik NM, Richardson DM (2014) Prosopis: a global assessment of the biogeography, benefits, impacts and management of one of the world's worst woody invasive plant taxa. AoB Plants 6: plu027.

[46] Shamseldein .H. A., Shadia .A. Omer, Eldow. M.Y:, Ali A. S., Sakata T. and Nawata.( 2013).Effect of Feeding Rations Containing Different Levels of Mesquite Pods on growth and Carcass Characteristics of Sudanese Nubian Goats. European International Journal of Science and Technology, 2 (9): 237244.

[47] Standing Committee on Agriculture (SCA).(1990). Ruminants Feeding Standards for Australian Livestock.CSIRO Publications, Australia.

[48] Szumacher-Strabel M., Potkański A., Kowalczyk J., Cieślak A., Czauderna M., Gubała A., Jędroszkowiak P., 2002. Influence of supplemental fat on rumen volatile fatty acid profile, ammonia and $\mathrm{pH}$ level in sheep fed a standard diet. J. Anim. Feed Sci. 11, 577-587

[49] Van Keulen, J. and Young, B. A. (1977).Evaluation of acib insoluble ash as natural marker in ruminant digestibility studies. Journal of Animal Science, 44 (2): 282-287.

[50] Van Soest, P.J. and Robertson, J.B. (1985).Analysis of Forages and Fibrous Foods. Cornell Univ. USA. 202 p.

[51] Zimmermann HG (1991) Biological control of mesquite, Prosopisspp.(Fabaceae) in South Africa.AgricEcosyst Environ 37:175-185. 